NBER WORKING PAPER SERIES

HOW DEBT MARKETS HAVE MALFUNCTIONED IN THE CRISIS

Arvind Krishnamurthy

Working Paper 15542

http://www.nber.org/papers/w15542

\author{
NATIONAL BUREAU OF ECONOMIC RESEARCH \\ 1050 Massachusetts Avenue \\ Cambridge, MA 02138 \\ November 2009
}

I am grateful to Tobias Adrian, Markus Brunnermeier, Ricardo Caballero, Jan Eberly, Mike Fishman, Gary Gorton, Bengt Holmstrom, Ravi Jagannathan, Jonathan Parker, Todd Pulvino, and Asani Sarkar for their comments. I also thank the editors of the Journal of Economic Perspectives, Timothy Taylor, David Autor and Chad Jones, for their comments. The views expressed herein are those of the author(s) and do not necessarily reflect the views of the National Bureau of Economic Research.

NBER working papers are circulated for discussion and comment purposes. They have not been peerreviewed or been subject to the review by the NBER Board of Directors that accompanies official NBER publications.

(C) 2009 by Arvind Krishnamurthy. All rights reserved. Short sections of text, not to exceed two paragraphs, may be quoted without explicit permission provided that full credit, including $\odot$ notice, is given to the source. 
How Debt Markets have Malfunctioned in the Crisis

Arvind Krishnamurthy

NBER Working Paper No. 15542

November 2009

JEL No. E43,E44,E52,G01

\begin{abstract}
$\underline{\text { ABSTRACT }}$
This article explains how debt markets have malfunctioned in the crisis, with deleterious consequences for the real economy. I begin with a quick overview of debt markets. I then discuss three areas that are crucial in all debt markets decisions: risk capital and risk aversion, repo financing and haircuts, and counterparty risk. In each of these areas, feedback effects can arise, so that less liquidity and a higher cost for finance can reinforce each other in a contagious spiral. I document the remarkable rise in the premium that investors placed on liquidity during the crisis. Next, I show how these issues caused debt markets to break down: fundamental values and market values seemed to diverge across several markets and products that were far removed from the "toxic" subprime mortgage assets at the root of the crisis. Finally, I discuss briefly four steps that the Federal Reserve took to ease the crisis, and how each was geared to a specific systemic fault that arose during the crisis.
\end{abstract}

Arvind Krishnamurthy

Kellogg School of Management

Northwestern University

2001 Sheridan Road

Evanston, IL 60208

and NBER

a-krishnamurthy@northwestern.edu 
The financial crisis that began in 2007 is especially a crisis in debt markets. For example, the stock market peaked in October 2007, with the Dow Jones Industrial Average near 14,000, and was still near 12,000 in August 2008. While the Dow Jones eventually fell to 6600 by March 2009 , most of that fall happened in late 2008. However, problems in debt markets like the mortgage-backed securities market had been in full swing since August of 2007. A full understanding of what happened in the financial crisis requires inquiring into the plumbing of debt markets.

Trades in debt markets are predominantly made by financial institutions - like banks, hedge funds, and insurance companies- rather than households. One key feature of markets in debt instruments is that whenever a trader wishes to make an investment, it must first raise money, either through a sale of existing financial assets, or by borrowing funds from another party. If funds can be raised fairly easily and quickly, debt markets should function fairly smoothly. But during a financial crisis, funds often cannot be raised easily or quickly. In such a setting, the fundamental values for certain assets can become separated from a time from market prices, with consequences that can echo into the real economy.

This article will explain in concrete ways how debt markets can malfunction, with deleterious consequences for the real economy. I begin with a quick overview of debt markets. I then discuss three areas that are crucial in all debt markets decisions: risk capital and risk aversion, repo financing and haircuts, and counterparty risk. In each of these areas, feedback effects can arise, so that less liquidity and a higher cost for finance can reinforce each other in a contagious spiral. I'll document the remarkable rise in the premium that investors placed on liquidity during the crisis. Next, I'll show how these issues caused debt markets to break down: indeed, fundamental values and market values seemed to diverge across several markets and products that were far removed from the "toxic" subprime mortgage assets at the root of the crisis. Finally, I'll discuss briefly four steps that the Federal Reserve took to ease the crisis, and how each was geared to a specific systemic fault that arose during the crisis.

It is important to keep in mind throughout this discussion that a "financial institution" is not just a traditional commercial bank. A number of different intermediaries do not take deposits directly from households, but in many ways functionally behave like banks in debt markets, even though they are not labeled banks. I use the term "financial institution" to refer to all of these entities, including insurance companies, hedge funds, brokers and dealers, and government-sponsored enterprises like Fannie Mae and Freddie Mac. 


\section{DEBT MARKETS AND FINANCIAL INSTITUTIONS}

Debt instruments can be usefully divided into loans and securities. The key distinction is that a "loan" is an investment that a financial institution has made and intends to hold to maturity. However, a security is an asset that is backed by a pool of loans originated by some financial institution, but which has subsequently been sold by the financial institution and is being held by another entity. A mortgage-backed security, where the backing is a pool of residential loans, is the typical security.

Table 1 provides a sense of the type and size of the debt markets that have been at the center of the financial crisis. The categories under "loans" are familiar ones: three categories of mortgage loans differentiated by the riskiness of the borrower (from more to less riskiness, subprime, Alt-A and prime), along with commercial real estate and corporate loans. Under the listing of securities, all instruments with the exception of corporate bonds are "structured finance" instruments in which a pool of underlying loans backs possibly multiple tranches of securities, distinguished by seniority. Typically, investors in junior tranches would take all the losses before those in higher mezzanine or even higher senior tranches would take any losses. The most complex of these structured investments are the collateralized debt obligations where the assets backing the securitization are themselves the junior or mezzanine tranches of other securitizations. Under the category of asset-backed securities, the underlying loans are non-mortgage lending, like car loans or credit card loans. Collateralized loan obligations are backed by corporate loans. Mortgage-backed securities are backed by either residential or commercial real estate loans. The total in Table 1 across both loans and securities is $\$ 18.64$ trillion.

The debt instruments in Table 1 are held by a number of financial institutions. Table 2 provides a sense of the main financial institutions in the United States, and the size of these institutions as measured by total assets. It is difficult to trace which financial institutions hold which instrument. They are distributed among commercial banks, investment banks (including brokers and dealers), hedge funds, insurance companies, some mutual funds, and the government-sponsored enterprises like Fannie Mae and Freddie Mac. For the most part, loans are held by commercial banks, with securities distributed across the different institutions. 
Moreover, insurance companies and government-sponsored enterprises hold less risky securities, while brokers and dealers, hedge funds, and commercial banks hold riskier securities.

\section{Three Considerations in Every Debt Market Purchase}

Every time a trader makes a purchase in a debt market, three considerations must enter the picture: risk capital, the haircuts in the repo market, and counterparty risk. This section explains each of these factors, and then discusses the role that each played during the financial crisis.

\section{Risk Capital and Institutional Risk Aversion}

A financial institution can raise capital in two ways: equity or debt. "Risk capital" refers to the equity capital. Consider the hypothetical balance sheet of a financial institution:

Assets $\quad$ Liabilities

\begin{tabular}{|l|l|}
\hline Treasury securities and cash $=50$ & Debt $=90$ \\
$\begin{array}{l}\text { Risky loans and debt instruments }=50 \\
\text { (like mortgage-backed securities) }\end{array}$ & Equity $=10$ \\
\hline
\end{tabular}

This financial institution raises $\$ 100$ by issuing $\$ 10$ of equity and $\$ 90$ of debt. It holds $\$ 50$ in liquid low risk securities such as Treasuries and $\$ 50$ in risky mortgage-backed securities.

Now suppose that the trader/management of the financial institution is considering selling some Treasuries and buying a higher return mortgage-backed security. Moreover, suppose that there are potentially large costs of financial distress (like risks of bankruptcy and job loss) that the trader/management accounts for in making investment decisions. Then, the portfolio choice decision will balance the higher returns on the mortgage-backed security against the increased probability of financial distress. A higher proportion of debt tends-or conversely, a 
lower level of risk capital-makes a financial institution more risk-averse in its portfolio choices. $^{1}$

In practice, this tradeoff of less risk capital leading to greater institutional risk aversion can manifest itself in different ways. For commercial banks, this tradeoff is embodied in regulatory capital requirements. Banks must have equity capital commensurate to the risk of their asset portfolio to keep the probability of financial distress sufficiently small. For other financial institutions, decision making at the level of a trader is often formulated in terms of a value-atrisk constraint, which essentially imposes a constraint on a trader's portfolio choice such that the probability of a large loss must fall below a given threshold. A firm with less risk capital, and hence a higher probability of financial distress, will impose tighter value-at-risk constraints on its traders. The tighter constraint induces risk aversion into the portfolio decisions of the trader. $^{2}$ The risk of financial distress is a consideration for all financial institutions that participate in debt markets. In this sense, risk capital considerations are broader than regulatory capital considerations.

Suppose that on our hypothetical balance sheet, the loans on the asset side fall in value to $\$ 45$. This financial institution then has remaining equity capital of $\$ 5$, and is closer to financial distress. Alternatively, suppose that the financial institution is a hedge fund, whose investors have a right to withdraw their equity and choose to withdraw $\$ 5$. Again, the financial institution will have only $\$ 5$ of equity capital left.

In both of these cases, when risk capital is reduced, unless the lost risk capital is immediately replaced by issuing $\$ 5$ of equity, the financial institution's reduced risk capital may affect its trading decisions. It may be less willing to purchase more mortgage-backed securities. If another investor is selling mortgage-backed securities, the financial institution will bid a lower price to purchase these securities.

\footnotetext{
${ }^{1}$ The corporate finance literature identifies another effect of low levels of capital on risk taking. When the decision maker (i.e. manager/trader) has little stake in the long-run survival of the financial institution, his shortrun interest will be to take excessive risks. This factor will cause financial institutions to seek out the riskiest investments. Empirically, during this and other crises, financial institutions seem to behave in a risk-averse fashion rather than in a risk-seeking fashion.

${ }^{2}$ A growing empirical literature documents how the limited risk capital of financial institutions affects asset prices: for some recent examples, see Gabaix, Krishnamurthy, and Vigneron (2007), Garleanu, Pedersen, and Poteshman (2007), and Greenwood and Vayanos (2008). Each focuses on a different asset market. To model the effect of risk capital on asset prices, one needs a theory of why risk capital is limited and why households (the ultimate investors) may not provide equity capital to finance all high return investments. See He and Krishnamurthy (2009a) for a model based on agency considerations.
} 
If a single financial institution loses risk capital, it may not affect equilibrium in debt markets. The affected financial institution may be more reluctant to acquire more assets, but others will readily buy these assets and asset prices will not be affected. On the other hand, suppose that the losses are across all financial institutions - that is the event is systemic as was the case after 2007. In the situation when aggregate risk capital is affected, it will have an effect on asset prices.

During the crisis, financial institutions have taken enormous losses in their risk capital. Table 3 reports an estimate of losses on traded securities and writedowns on loans by the main U.S. financial institutions that hold debt instruments, reported for some of the main classes of debt securities by the IMF in its October 2008 Global Financial Stability Report. The total across these assets classes for banks, insurers and hedge funds is $\$ 985$ billion. The losses and writedowns are split across real estate related debt instruments (loans, mortgage-backed securities, some asset-based securities and collateralized debt obligations) and corporate and consumer loans (asset-based securities and collateralized debt obligations, corporate debt and collateralized loan obligations). The writedowns are as reported by the financial institutions, and may be an underestimate of losses. The fundamental sources of the losses are falling real estate prices, along with declines in corporate profitability and household income.

The decline in risk capital can be greater than the losses shown here. For example, the hedge fund and other category has losses on these assets totaling $\$ 135$ billion. Hedge fund risk capital has in fact fallen more than this amount because of investor redemptions. Up until early 2009, these redemptions are estimated to be around $\$ 277$ billion (Lipper TASS Hedge Fund Asset Flows Report).

The cumulative reported losses across banks, insurers, and government sponsored enterprises from the second quarter of 2007 to the second quarter of 2009 is $\$ 971$ billion; total capital raised is $\$ 732$ billion, with a good part of this due to the U.S. Treasury capital injection plan (TARP), according to an estimate by Bloomberg. This estimate covers a larger set of financial institutions than that of Table 3, but excludes hedge funds. As noted above, the losses are as reported by the banks, and are plausibly an underestimate of actual losses. The difference between losses and capital raised of around $\$ 239$ billion is the current shortfall to the financial sector. 
The widespread loss in risk capital seems fully sufficient to reduce liquidity in debt markets in a way that, as a minimum, puts downward pressure on prices. A perverse feedback effect arises here that has played a part in the financial crisis. Risk capital falls, causing institutional risk aversion to rise and asset values to fall, causing risk capital to fall further, and so on. ${ }^{3}$

\section{Repo Financing and Haircuts}

In practice, financial institutions raise equity capital infrequently. For most financial institutions that actively trade in debt markets on a day-to-day basis, cash needs are met by borrowing through repurchase agreements. A description of the repurchase agreement-commonly referred to as a "repo" - should help to clarify why.

A repo agreement is a loan that is collateralized by financial securities. Suppose that a hedge fund wished to purchase a mortgage-backed security for $\$ 100$. Consider two options: 1) raise $\$ 100$ from hedge fund investors in the form of equity capital (or use some of the equity capital previously given by investors); or 2) use the $\$ 100$ worth of mortgage-backed security as collateral to take out a loan. If the trader chooses the latter strategy, a lender will forward $\$ 100$ minus a haircut to the hedge fund. Haircuts for prime mortgage-backed securities, before the crisis in early 2007, were 2.5 percent of value, so that the hedge fund would have been able to borrow $\$ 97.50$ in this way. Lenders typically set the haircut high enough so that they need not do any detailed analysis of the underlying collateral. For the hedge fund, a repo loan is easily arranged -it just takes a phone call. Hordahl and King (2008) of the Bank of International Settlements estimate that the repo market in 2007 was roughly \$10 trillion in size.

Risk capital remains important here. The repo lender provides $\$ 97.50$, but the hedge fund needs $\$ 2.50$ from its equity investors to have the $\$ 100$ needed to purchase the security. In practice, the $\$ 2.50$ will not come from a new sale of equity, but rather from a past sale of equity to investors or from reinvesting past returns on equity. Finally, while I am using a hedge fund as my example, it should be clear that my description applies to any financial institutionfor example, the trading desk at a bank - that is actively trading a debt instrument. ${ }^{4}$

\footnotetext{
${ }^{3}$ See He and Krishnamurthy (2009b) for a model of this risk capital effect and a quantitative evaluation of government policies to remedy the risk capital feedback effect.

${ }^{4}$ An important question lurks here which I am only touching on: Why don't financial institutions only raise equity capital? What is the role of repo financing? The issue is not settled. Diamond and Dybvig (1983) and Gorton and Pennacchi (1998) suggest that savers/households have a demand to hold their savings in a liquid asset and that financial institutions satisfy this demand through the structure of their liabilities. Krishnamurthy and Vissing-
} 
The magnitude of the required haircut will affect purchases in the debt market. Suppose that the hedge fund had $\$ 2.50$ of equity capital, but the mortgage-backed security haircut doubled to 5 percent. ${ }^{5}$ Then, the maximum size of balance sheet for the hedge fund would be $\$ 50$ of mortgage-backed security financed by $\$ 47.50$ in repo debt.

The repo market lies at the heart of all debt markets. On the demand side of this market, if the trading desk of a financial institution had to go to its equity holders every time it needed the cash to purchase a debt security, there would be almost no secondary market trading in debt securities. The speed of transaction in the repo market plays an important role in supporting the trading and liquidity of debt markets. As shown in Figure 1, a collection of Wall Street banks (for example, Goldman, Sachs, Morgan Stanley, JP Morgan Chase) are at the center of the repo market. On the repo lending side, the typical cash investor in a repo is a money market fund that is looking for a relatively safe place to invest a large amount of cash over a short period. During less turbulent times, debt instruments are low volatility assets. To the cash investor, repo is attractive-say, relative to placing money in a large time deposit in a bankbecause it is over-collateralized. The haircut of 2.5 percent on mortgage-backed security in a normal market provides sufficient protection against losses that lenders are comfortable with repo.

When repo lenders determine haircuts, they have two main considerations: 1) the probability of a borrower defaulting on the repo loan; and 2) the recovery value when liquidating the collateral in the secondary market, if default occurs. The first of these considerations is reasonably clear, and for these short-term loans it is usually quite small. The second consideration has played a dramatic role in the crisis. The secondary market for mortgagebacked securities is less liquid than the secondary market for Treasuries. As a result, a lender will be more concerned when lending against mortgage-backed security collateral than Treasury collateral. Prior to the crisis, mortgage-backed security haircuts were around 2.5

\footnotetext{
Jorgenson (2008) offer empirical evidence that this demand is quantitatively large and has significant effects on asset prices. Repos can meet this need because they are typically short-maturity (hence, de-factor liquid), quick to transact, and there is a large pool of financial securities that can serve as collateral to back repo. For a discussion of the repo market and securitization from this point of view, see Holmstrom (2008) and Gorton (2009). Caballero and Krishnamurthy (2009) argue that the demand for safe/liquid securities over the last decade, driven by global imbalances, helps to explain the increase in financial sector leverage prior to the current crisis.

${ }^{5}$ In practice, if the hedge fund has a position of $\$ 100$ of securities that it is financing in the repo market with the haircut of 2.5 percent, and the haircut suddenly increases to 5 percent, the hedge fund will be asked to either put up another $\$ 2.50$ of equity capital, or halve the size of its security position.
} 
percent while Treasury haircuts were 2 percent, as shown in Table 4. During the crisis, liquidity considerations have been magnified, with dramatic effects on repo haircuts. ${ }^{6}$

Table 4 provides a sense of how repo haircuts have evolved over the crisis for a number of debt instruments. For each time period and debt instrument, I am reporting a typical haircut faced by a financial institution. In practice, haircuts vary across borrowers at every given point in time; for example, a hedge fund typically will face higher haircuts than a large Wall Street bond dealer. The data in the first three columns is from the Depository Trust and Clearing Corporation (provided by Tobias Adrian of the New York Fed), with the column for fall of 2008 filled out from reports of investment banks.

Haircuts on all classes of securities rise during a financial crisis. ${ }^{7}$ This occurs is in part because the average borrower is less creditworthy, so that a lender must account for a higher probability of default. (This point is discussed further in the next section on counterparty risk.) The haircuts rise the least for the most liquid securities. For example, short-term U.S. Treasuries have remained very liquid through the crisis, and also have seen no change in haircuts. On the other hand, the more exotic asset-backed securities with the least liquid secondary markets have the highest haircuts in the fall of 2008. Gorton and Metrick (2009) provide further information on the evolution of haircuts on some of the more exotic debtmarket instruments, and note that for some of the lower-rated tranches of securitizations, the repo haircuts in the fall of 2008 went to 100 percent, indicating that the repo market essentially closed.

As one might expect, rising haircuts during the financial crisis were accompanied by a shrinkage of the repo market. We can get a sense of this shrinkage using data from the Federal Reserve Bank of New York. They report repo activity by bond dealers where the underlying collaterals are U.S. Treasury securities, mortgage-backed securities insured by government-sponsored Agencies, as well as government-sponsored Agency debt. This data do not include any of the lower quality asset-backed securities that have been most severely affected in the crisis. ${ }^{8}$ In January 2007, the repo activity was about $\$ 350$ billion, measured as a monthly rolling average. By April 2008 it had risen to $\$ 450$ billion. But then it fell sharply in the rest of 2008 , dropping to

\footnotetext{
${ }^{6}$ For further details on the repo market, see Adrian and Shin (2008) and Gorton and Metrick (2009). For a paper modeling the determination of repo haircuts and effects on asset prices see Brunnermeier and Pedersen (2007).

7 In practice, there are two dimensions of adjustment on the repo contract: the haircut and the interest rate on the repo loan, the repo rate. Repo rates, on the less liquid securities, also rise as the crisis worsens.

${ }^{8}$ Note that these repo volumes, in the hundreds of billions, are smaller than $\$ 10$ trillion as reported by the Bank of International Settlements. The difference is because the BIS numbers cover a greater number of securities that serve as collateral as well as a larger number of financial institutions (including foreign banks).
} 
$\$ 250$ billion by January 2009, and staying at that lower level through May 2009. Many observers have referred to the decline in the repo market in the second half of 2008 as "deleveraging" - that is, borrowers take on a lower level of repo market loans.

As noted earlier, the liquidity of debt markets is facilitated by trading desks and hedge funds. As repo haircuts rise, these players' activities are curtailed. A perverse feedback effect arises here that has played a part in the financial crisis. Liquidity falls, causing repo haircuts to rise, causing liquidity to fall further, and so on. ${ }^{9}$

\section{Counterparty Risk}

The typical debt-market transaction involves a counterparty - some other financial institution that is part of the transaction. Thus, risk in a debt market investment is not limited to the interest and capital gains from the asset that is purchased, but also lies in whether the counterparty makes good on its obligations.

Consider the case of the hedge fund borrowing in the repo market. In practice, the lender to the hedge fund will be an investment or commercial bank. Suppose that the investment bank declares bankruptcy immediately after the repo transaction is initiated. In this case, the hedge fund will have $\$ 97.50$ of the bank's cash, but the bank will have the hedge fund's collateral -$\$ 100$ worth of the hedge fund's securities. ${ }^{10}$ The hedge fund may pursue its claim on the bank of $\$ 2.50$ (or the replacement value of the securities) in bankruptcy proceedings. But this process is a slow one, possibly occurring over a year or so. In this case, the fast repo transaction now becomes a slow transaction. We say in this case that the hedge fund bears counterparty risk in arranging the repo with the bank. Somewhat counterintuitively, a hedge fund must be careful in selecting its lenders! As counterparty risk grows, financial institutions reduce their reliance on repo, but then have to shift to slower financing arrangements. Inevitably, the trading decisions of financial institutions are affected, and with that, the prices and liquidity of the traded debt instruments suffers.

\footnotetext{
${ }^{9}$ Some papers have modeled closely related feedback mechanisms. Brunnermeier and Pedersen (2007) present a model in which a rise in the volatility of an asset feeds back into a higher haircut, and a further rise in volatility ("haircut/margin spiral"). Garleanu and Pedersen (2007) present a model of the feedback between risk capital and secondary market liquidity.

${ }^{10}$ This example of counterparty risk is based on a "bilateral" repo agreement which is the typical agreement between a hedge fund and a bank. Repos are also structured as "trilateral" agreements where a particularly strong bank stands between all parties and holds the collateral. The trilateral repo is thus less subject to counterparty risk.
} 
Counterparty risk arises in any bilateral transaction. Another common example of a transaction with counterparty risk is the interest rate swap. A "LIBOR interest rate swap" is an agreement between two parties - say, bank A and bank B - where both have obligations to make payments to the other. The payments depend on what happens to interest rates, or more specifically, what happens to the London Interbank Overnight Rate, which is an index that serves as a benchmark borrowing cost for large banks. The index is published daily by the British Banker's Association, based on a survey of several large banks.

A 10-year \$100 million interest rate swap agreed to between bank A and bank B will have bank $A$ responsible for paying interest to bank $B$, calculated based on LIBOR, as quoted on a series of pre-specified dates, applied to $\$ 100$ million of principal. The dates might be specified as every six months over the next ten years. Bank B in turn is obligated to pay, on the same 20 payment dates, a fixed rate that is agreed to when the deal is initiated. This fixed rate is referred to as the "swap rate." Clearly, the swap rate at initiation will be based on expected LIBOR over the next 10 years.

This transaction clearly involves counterparty risk. Bank A will be worried about entering into such a transaction with Bank B, if Bank B's credit quality deteriorates (and vice-versa). In this case, Bank A may ask for extra collateral from Bank B, or may choose to terminate (or not initiate) the interest rate swap. Increasing counterparty risk triggers demands for greater collateral and reduces the volume of transactions in interest rate swaps.

A credit default swap is a financial instrument to address counterparty risk. In this case, for example, Bank A might purchase a credit default swap, making an up-front payment and then being protected against Bank $B$ being unable to make the scheduled payments. In this way, the price of credit default swaps is a measure of counterparty risk. Figure 3 graphs the five-year credit default swap rates for four major financial institutions over the period from March 1, 2008 to November 10, 2008. The "credit default swap rate" measures the dollar cost that must be paid as an annual insurance premium to insure against default on a notional $\$ 10,000$ facevalue of bonds. The roughly $\$ 1,000$ premium for Morgan Stanley in October 2008, reflects a very high default probability, implying a (risk-neutral) probability of Morgan Stanley going bankrupt over the next five years of roughly 60 percent. $^{11}$

\footnotetext{
${ }^{11}$ To understand where the 60 percent probability comes from, consider the following computation. Suppose the recovery rate in default is 50 cents on the dollar for Morgan Stanley and it costs $\$ 1,000$ per year to purchase insurance on $\$ 10,000$, then the annual default probability is 20 percent. Then over five years the probability that Morgan Stanley will default is approximately 60 percent, following basic probability rules.
} 
Figure 3 indicates three events in which the bankruptcy issues come to the forefront. First, the failure of Bear Stearns in March 2008 raised concerns that other investment banks would also fail. Thus, the credit default swap rates for Morgan Stanley and Goldman Sachs rise in this event, while the parallel rates for Citigroup and Bank of America, which are commercial banks, do not increase as much. Second, credit default swap rates increase by an order of magnitude following Lehman Brothers' failure in September 2008 and AIG's near-bankruptcy. The AIG event is particular important in this period. AIG went from being a high quality AA-rated insurer to near-bankruptcy in one week. The speed of this decline suggested to many market participants that other financial firms could decline as quickly. In addition, AIG was the counterparty on a large volume of swaps with other financial institutions. Market participants grew concerned that the failure of AIG would lead to default on many of these swap obligations, leading to large losses at other financial institutions. Third, credit default swap rates come down somewhat in October 2008. The U.S. Treasury purchased equity capital in financial institutions in October, thus reducing the probability of bankruptcy. In addition, Goldman Sachs and Morgan Stanley became commercial banks.

\section{LIQUIDITY}

I have thus far discussed how falling risk capital, rising repo haircuts, and increased counterparty risk can impinge on the actions of financial institutions. More specifically, I've argued that these factors reduce liquidity in debt markets. Declining liquidity reflects two considerations. Financial institutions that provide the secondary market in debt instruments reduce their purchasing for these reasons. In addition, during a financial crisis many investors become more averse to owning illiquid investments, preferring to keep their investments in liquid assets. $^{12} 13$

\footnotetext{
12 Investors' aversion to illiquidity and demand for liquid assets is present in most crises. Caballero and Krishnamurthy (2008) present a model showing how a rise in Knightian uncertainty can trigger this behavior. They argue that Knightian uncertainty has played an important role in this and past crises. Holmstrom and Tirole (1998) and Eisfeldt and Rampini (2008) show how the anticipation of binding financial constraints can trigger the demand for liquid assets. Vayanos (2004) shows how a hedge fund manager, who fears redemptions by equity investors, will demand more liquid assets.

13 Other liquidity problems have also been present in debt markets. For example, Fishman and Parker (2009) show how adverse selection problems in loan markets can lead to a fall in prices and reduced lending/trading. I do not touch on adverse selection issues in this paper, although they have surely played a role in the crisis.
} 
Claims of reduced liquidity can sometimes be difficult to document, but in this section, I offer specific evidence of liquidity problems in debt markets. Specifically, I compare pairs of assets where one asset is more liquid than the other, but which are otherwise similar. I show that the price of the illiquid asset has fallen in the crisis relative to the price of the liquid asset. In addition, I will emphasize the connection between liquidity and maturity: that is, a shorter-term security is more liquid, so a desire for greater liquidity will tend to favor shorter-term securities over longer-term ones.

As my first example, the Federal National Mortgage Association (FNMA) issues bonds to finance its activities. These bonds resemble U.S. Treasury bonds in many ways, except that they do not carry the explicit guarantee of the U.S. Government and the secondary market for FNMA bonds is less liquid than that of Treasury bonds.

The solid line in Figure 4 graphs the spread between five-year FNMA bonds and five-year Treasury bonds from January 2007 to December 2007. In January 2007, the spread is near 20 basis points, which in part is a compensation for the explicit guarantee of Treasury bonds and the superior liquidity of Treasury bonds. By mid-2008, the spread rises to 80 basis points. The U.S. Government placed FNMA in a conservatorship on September 7, 2008, and guaranteed that it would ensure that the book value of capital remained positive. For all intents and purposes, this announcement was a guarantee of debt, although it left open the possibility that the government would re-privativize FNMA and remove the debt guarantee in the future. The spread to Treasuries fell to 58 basis points on September 12, 2008. In the turmoil of the fall of 2008 , the spread reversed direction and increased again, reaching its highest levels of near 140 basis points. To provide some perspective on these spreads, the average FNMA to Treasury spread from 1958 to 2004 was 38 basis points, and the annual standard deviation of the spread was 22 basis points.

I interpret this event as reflecting a dramatic flight to liquidity by investors. That is, investors increased their valuation of the liquid Treasury relative to the less liquid FNMA bonds, causing the spread to rise. $^{14}$

14 The other plausible interpretation of the increase in the spread is that the market grew to doubt the government's support of FNMA. This hypothesis however is hard to reconcile with a second fact: the spread between two-year FNMA bonds and two-year Treasury bonds (dashed line) increased to 170 basis points in the same period. That is, the odds of the government removing its positive-capital guarantee should be higher over the next five years than over the next two years. On the other hand, the demand for liquidity should be expected to lessen over time as the crisis passes. Hence the demand for liquidity effect should have a greater impact on the 
My second example of the flight to liquidity during the financial crisis compares interest rates on Treasury bills to the federal funds overnight index swap rate. Figure 5 graphs the yields on three-month Treasury bills and the three-month overnight index swap rate. The "overnight index swap rate" is a market measure of the expected overnight federal funds rate, in this case, for the next three months. ${ }^{15}$ By comparing three-month Treasury bills to the three-month index swap rate, rather than the overnight federal funds rate, we can be sure that there are no anticipated changes in the federal funds rate that affect the comparison. For reference, I have also graphed the overnight Federal Funds target rate in dashed line on the figure.

Notice the movement in the Treasury bill yield in March 2008 at the time of the Bear Stearns failure, and again in the turmoil of fall 2008. The Treasury bill yield in particular falls during these events. The overnight index swap rate does not change appreciably, indicating that the Federal Reserve's policy rate is stable through these market gyrations. The movements are also large: the Treasury bill yield falls over 1 percent relative to the overnight index swap. The Treasury bill is the perhaps the most liquid instrument in the debt markets. These events also illustrate how investors increase their valuation of the most liquid Treasury securities relative to other securities.

Once you start looking, examples of decreased liquidity in the debt markets in late 2008 are apparent in many comparisons like these. For example, one can look at the yield spread between the most recently issued 30-year Treasury bond and the 30-year bond that was issued two auctions prior. The most recently issued bond is known as the on-the-run bond, and bonds issued in prior auctions are off-the-run bond. The on-the-run bond is more liquid than the offthe-run bond (Krishnamurthy, 2001). Not surprisingly, the interest rate spreads between these two types of bonds rise in the fall 2008 turmoil and remain high through March 2009, before falling back to near zero recently-a pattern similar to the others I have presented.

two-year bond than the five-year bond. Indeed, one would expect that the increased demand for liquidity in a crisis is most evident in the behavior of short-maturity bonds, which is what I show in Figure 5.

${ }^{15}$ Formally, the overnight index swap rate is the fixed rate on a three-month interest rate swap, whose floating leg is based on the average overnight federal funds rate over the next three months. Following on the previous discussion of interest rate swaps and counterparty risk, one may ask whether the three-month overnight index swap rate is distorted by counterparty risk concerns. This is possible, but does not seem to be the case because the three-month overnight index swap rate tracks movements in the overnight federal funds rate fairly closely. 
Liquidity and the maturity of debt instruments are closely related: for example, a three-month loan is less liquid than an overnight loan. As investors demand for liquidity rises, they will therefore be less willing to supply 3-month loans relative to overnight loans. This phenomenon has had important effects on many key short-term bond markets.

My third main example of a shift in liquidity focuses on this maturity relationship. Figure 6 compares the ratio of overnight repo financing obtained by primary dealers - like the major Wall Street investment banks as they existed in 2007-relative to the costlier longer-term repo financing (defined as total financing minus overnight financing for an average time of one month). The repo activity is for Treasury, mortgage, and government-sponsored agency bonds only and thus does not include some of the lower quality asset-backed securities that have been most severely affected in the crisis. I present a rolling monthly average of this ratio to smooth out some of the high frequency fluctuations. The data is from the Federal Reserve Bank of New York. The data reveal a gradual shift towards overnight financing. In the summer of 2007 period, the ratio is a little above 1.5 . By early 2008, the ratio approaches 2 . In the fall of 2008 turmoil, the ratio reaches a peak of around 3.5 before declining in early 2009 .

For institutions actively trading in bond markets, relying on overnight financing is inherently more risky than relying on longer-term financing. ${ }^{16}$ For example, suppose a trader wishes to bet that Federal National Mortgage Association (FNMA) bonds are underpriced. To do so, the trader buys the FNMA bonds (using some risk capital) and borrows using the FNMA collateral in the repo market. If the trader thought that the underpricing would resolve over the next three months, then ideally, the trader would also repo finance out to three months. If, alternatively, the trader tried a strategy of rolling over overnight repo for three months, the trader faces the risk of being unable to renew the financing in the interim and thus being forced to exit the position prematurely. Thus, a decrease in the maturity of repo financing means an increase in its riskiness - which will make this trade less likely to attempt to exploit perceived arbitrage opportunities.

The maturity contraction I have discussed in the context of the repo market appears to have taken place across many different financing arenas: that is, a greater preference for liquidity has led to a shortening of debt maturity in many markets, with attendant effects on activity.

\footnotetext{
${ }^{16}$ He and Xiong (2009) model how an increased reliance on short-term financing can lead to a coordination failure whereby some lenders choose not to renew their financing, anticipating that other lenders will also not renew financing, precipitating bankruptcy of the borrower.
} 
Many observers note the same phenomena in the interbank market for federal funds loans; indeed, Federal Reserve Chairman Ben Bernanke (2008) commented on the "illiquidity" problem in the interbank market. Throughout this crisis, the interest rate on interbank loans for a three month maturity far exceeded the overnight federal funds rate. Monetary policy only directly controls the overnight rate. In a normal liquid market, market expectations and arbitrage forces transmit policy changes in the overnight rate to longer term rates, such as the three month interest rate, thereby affecting the relevant cost of borrowing for firms and households. However, in the illiquid environment of the crisis this transmission has been impaired, reducing the effectiveness of monetary policy. Unfortunately, it is hard to obtain data analogous to Figure 6 for the interbank market to clearly document these effects.

My final main example of liquidity issues focuses on one market where these liquidity/maturity effects are straightforward to perceive: the commercial paper market. The commercial paper market is an important source of quick funds for high-grade firms in the corporate and financial sectors. If a company like General Electric (GE) needs to raise \$100 million quickly, it can do so in the commercial paper market. However, the commercial paper market is also used as an ongoing source of funds, by borrowing anew in this market ("rolling over loans") as prior obligations become due. In June 2008 , GE had $\$ 63$ billion in commercial paper outstanding. This was one-third of GE's short-term borrowings and over 10 percent of its total borrowing. The predominant buyers of commercial paper are money market mutual funds.

The solid line in Figure 7 indicates the total volume of short-term financing that is issued on any given day in the key period of summer and early fall 2008. The data is for loans from 1-9 days, but much of the financing is probably overnight. The dashed lines correspond to longer term financing. What looks like a relatively small decline in issuance of longer-term financing (dashed lines) generates a larger rise in the issuance of short-term financing, because it means that more firms must return to the market day after day to borrow. When companies are forced into the commercial paper market on a daily or weekly basis, instead of every month or two, they rightfully perceive that they face an increased risk of being unable to finance themselves. At least some firms will respond to the shortening of maturities by cutting back on expenditures immediately-which is one of the ways that the effects of a credit contraction can be exacerbated.

\section{Price Effects on Debt Securities}

I have described how the perennial issues of risk capital, repo financing and haircuts and counterparty risk can reduce liquidity in debt markets. The mechanisms I have described also suggest a vicious cycle: a decline in asset values reduces risk capital, raises haircuts, and increases counterparty risk. In turn, purchasers in debt markets will be less eager to buy. There 
is a flight to more liquid and shorter maturity debt instruments. In some cases, disfavored debt markets can essentially cease to exist for a time-as when haircuts for certain debt instruments reach 100 percent. But even before that outcome, the lack of liquidity and purchasers in debt markets can mean that arbitrage fails to perform well, and fundamental prices can diverge from market prices. ${ }^{17}$ Shleifer and Vishny (1997) dub these kinds of market problems as a "limit to arbitrage."

Here, I present two examples to illustrate how these limits of arbitrage problems have affected the prices of debt securities. The two examples represent relatively simple debt instruments: interest rate swaps and mortgage-backed securities securitized by the government agencies. These markets are admittedly at the periphery of the financial crisis. However, because they are relatively simple, they are a good laboratory to isolate the limits of arbitrage effects I have discussed. I will show that even these simple instruments demonstrate anomalous price patterns. The broader lesson to take-away from these examples is that if prices on these simple securities are distorted because normal arbitrage forces do not operate, it is likely that prices on more complicated "toxic" assets are even more distorted. Moreover, to the extent that these "toxic" assets have inflicted the largest losses on financial institutions, it likely that a component of these losses are due to limits of arbitrage problems.

\section{Interest Rate Swap Spread}

Interest rate swaps are largely used by corporations and banks to manage the interest rate risk in their assets and liabilities. If a corporation wants to enter into a swap, it contacts a bond dealer - typically the large Wall Street banks - and requests a quote from a trader. The bank sets a price, and if a transaction occurs, the bank is the counterparty on the swap with the corporation. The swap market is large and active. The International Swap Dealers Association reports in 2008 that the total volume of interest rate swaps transactions outstanding was $\$ 403.1$ trillion.

Figure 8 graphs the 30-year interest rate swap spread from June 2008 to June 2009. The 30year swap spread measures the difference between 30 -year U.S. Treasury bond rates and the interest rate swap rate for trading a fixed interest rate against floating (LIBOR) interest rates,

\footnotetext{
${ }^{17}$ Gromb and Vayanos (2002) present a model in which arbitrage exists in the asset markets because of financial
} constraints on the arbitrageurs. 
for 30 years. The figure also graphs the underlying Treasury and swap rates. Since the swap rate reflects an interest rate from major banks (LIBOR), which in turn reflects bank credit risk, swap rates are almost always higher than Treasury rates.

Since September 2008, this normal relationship has been overturned: 30-year swap rates have been below Treasury rates. During fall 2008, swap rates fall faster than Treasury rates to cause the spread to fall negative. On November 28, 2008, the 30 year swap rate was 40 basis points below the 30-year Treasury. Market participants ascribe this reversal of the normal pattern to problems stemming from the bankruptcy of Lehman Brothers. Lehman had entered into swap contracts with corporations, where Lehman was obligated to pay the fixed rate on the swaps. With Lehman's demise, these corporations had to re-contract these swaps with other bond dealers. This dynamic led to the swap rate falling. It is not surprising that the demand from corporations to enter into pay-fixed swaps reduced the swap rate. What is surprising is that the swap rate fell below Treasury rates.

To see why the negative swap spread is anomalous, consider the following trade. An arbitrageur could purchase $\$ 100$ worth of a 30 -year Treasury bond, say at 4 percent. Using the Treasury as collateral, the arbitrageur can do a repurchase agreement where the arbitrageur pays the repo rate to finance this purchase, and then rolls over this financing every three months in the repo market, paying the then prevailing repo rate. The arbitrageur can then do a fixed rate swap paying 3.60 percent and receiving the three-month LIBOR - that is, where the LIBOR rate is reset every 3 months. The cash-flows from these trades are as follows:

Treasury Purchase: $\quad$ Receive $4 \%$ per annum for next 30 years

Pay 3-month repo rate, rolled every 3 months, to finance the purchase

Swap Trade: $\quad$ Pay $3.60 \%$ per annum for next 30 years

Receive 3-month LIBOR rate, reset every 3 months, for next 30 years

First note that the trade essentially eliminates all interest rate risk. If interest rates rise, both the three-month repo rate as well as the three-month LIBOR rate will rise. If they rise one-forone, the change in interest rates is offset. The only source of interest rate risk is if they don't rise one-for-one - but in this case, such risk works actually works in the arbitrageur's favor.

LIBOR rates have been between 100 and 300 basis points above the Treasury repo rate recently; historically, this spread is always positive, but averaged closer to 40 basis points. Thus, based on current values, the difference between the LIBOR receipt and the repo payment 
earns the arbitrageur 100 to 300 basis points currently. While this profit may revert to 40 basis points eventually, it will always remain positive. The latter is because LIBOR reflects unsecured bank financing, and repo rates reflect financing secured by Treasuries as collateral. When the financial world goes into a panic, the spread rises (as has been the case recently), so that the "risk" goes in the arbitrageur's favor. The trade also earns a fixed rate differential of 40 basis points. Moreover, if the swap spread turns positive, the arbitrageur can unwind the trade at a profit. The trade has "positive carry" and substantial upside.

Why is this trade not being done in sufficient size to eliminate the negative swap spread? The factors discussed earlier have plausibly limited arbitrageurs' willingness to take on this trade.

The trade requires risk capital, but there was little risk capital in the marketplace during this time period, especially after September 2008. The repo requires a haircut, which was larger than usual, as well as collateral to guarantee the swap payments. Counterparty risk has played a role in the repo market: lenders may not be willing to lend as freely to all arbitrageurs to buy the Treasuries. Counterparty risk also affects the interest rate swap, and arbitrageurs may be less willing to enter such a bilateral contract with another financial institution at this time. The fact that these factors have prevented an anomalous market relationship from reverting back to the norm indicates the role that broken plumbing has played in debt markets.

\section{GNMA Mortgage-Backed Security}

Let us consider an asset that is one step more complicated to value, but also one step closer to the heart of the current crisis. Figure 9 graphs the option-adjusted spread on the 30-year 6 percent GNMA (Government National Mortgage Association) mortgage-backed security. Since a mortgage offers a homeowner the option to prepay, to compare the mortgage-backed security yield to other bond market interest rates, one has to strip out the value of the option. The option-adjusted spread presented in the figure is computed based on Bloomberg's built-in prepayment model. Thus, the spread reflects only the excess return one can earn from buying the mortgage-backed security. Although Bloomberg's option value computation is probably not as fine-tuned as an investment bank's pricing model, my discussion focuses on how the spreads move up at the "right" times, rather than on the absolute level of these spreads.

The solid line graphs the spread on the GNMA security versus the interest rate swap rate (which is, as explained a few paragraphs back, the fixed interest rate one would pay in exchange for a floating LIBOR interest rate). The GNMA security carries the explicit "full faith and credit of the U.S. government" and are therefore as safe as Treasuries. GNMA securities have much higher 
underwriting standards than subprime mortgages, so that the typical equity buffer is on the order of 20 percent. Moreover, if a homeowner defaults on a mortgage, the U.S. government absorbs any losses, paying par to the holder of the mortgage-backed security. Thus, there is no default issue with these securities, and the remaining risks (as with all mortgage-backed securities) are prepayment risk and interest rate risk. The spread between the GNMA bonds and interest rate swap rates is then partly a compensation that an investor requires for bearing prepayment risk and interest rate risk. During normal periods, the compensation investors require for bearing these risks are fairly small. Indeed, prior to February 2008, the spread is negative, reflecting the low credit risk (compared to the interest rate swap rate) that comes with the explicit government guarantee.

The first blip upwards in the spread is in March 2008 with the Bear Stearns event. Bear Stearns was an important player in the mortgage market, and thus one reading of this graph is that risk capital devoted to pricing and bearing the risks of mortgage-backed securities shrank in the aftermath of the Bear Stearns event. The next blip upwards in the spread is at the end of July 2008 , corresponding to the problems with the private mortgage giants, Federal National Mortgage Association ("Fannie Mae") and the Federal Home Loan Mortgage Corporation ("Freddie Mac"). Although GNMA was not directly affected in this event, the problems at Fannie Mae and Freddie Mac further shrank the risk-capital in the mortgage market. The spread increases again the week of September 26, 2008. Note that since the spread is measured relative to swaps, and LIBOR was also affected during this event, the spread rise is not initially dramatic. Finally, the spread in the 2009 period falls as the crisis has abated. But even by mid-2009, the spread had not returned to negative values.

Over this period, the spread moves from -25 basis points to over 150 basis points. This is a dramatic change in the return investors require for bearing mortgage-backed security risks, especially when such securities carry an explicit government guarantee and the comparison rate (swaps) do not. Note also that this large movement in spreads dwarfs any problems stemming from using interest rate swaps as the comparison rate. As discussed previously, interest rate swap rates have themselves been distorted in the crisis, but the magnitude of such distortion is around 40 basis points through this period. One can also construct the spread between GNMA bonds and Treasuries and produce a similar picture to Figure 9.

Apparently arbitrage is limited here as well. While I am pointing to only a few data points to make my argument, more complex work studying longer time-series and cross-sections of mortgage-backed security shows that the mortgage-backed security market does exhibit significant limits of arbitrage effects (Gabaix, Krishnamurthy, and Vigneron, 2007). Why has this spread has remained at high levels rather than returning to the early 2007 levels? Again, to buy the GNMA mortgage-backed security requires risk capital, of which there is little. Moreover, 
the purchase must be financed in the repo market and repo haircuts have risen. Finally, to earn the high return as depicted in the figure, a trader must also do offsetting trades in swaps, and that carries counterparty risk.

For financial institutions, the pricing effects reflected in the behavior of the GNMA mortgagebacked security is important because it suggests that the value of financial claims reflecting future mortgage risk is especially low. Hence the losses on financial institutions balance sheets are larger than they would otherwise be if prices were at fundamental value. For households and the mortgage market more generally, the high GNMA spread helps explain why mortgage rates had remained high in the fall of 2008, despite the general drop in interest rates as reflected by the lower federal funds interest rate or the lower rates on Treasuries.

\section{Government Policy to Plug the Leaks}

Many academics and policymakers think that asset prices during the crisis have deviated significantly from fundamental values and that this deviation is part of the problem affecting financial institutions. For example, if mortgage and credit assets, which banks hold in plenty, are priced below fundamental values, then banks will be assessed larger losses than they otherwise would. This in turn can lead to binding bank capital requirements and a reduction in bank lending, thus resulting in a deeper recession.

Of course, it is ultimately hard to assess fundamental value on the most toxic mortgage-backed securities, which are entangled in subprime mortgages as well as tranches of claims that bear different losses, as well as mixed with credit default swaps. Claims by banks that their assets are really worth substantially more than the market price should be rightly treated with some suspicion by bank regulators and investors. On the other hand, the evidence I have presented shows that the basic financial plumbing that enforces fundamental value relationships in debt markets has been impaired during this financial crisis. There is circumstantial evidence for deviations between fundamental value and market value in certain debt markets.

We can view many of the government's policy initiatives from this perspective: they are different ways to clear the plumbing in debt markets, and thus overcome the limits of arbitrage 
problems, with the hope that it will speed the process of diminishing any gap between market prices and fundamental prices. Consider four government initiatives from the last few years in this light.

First, the U.S. Treasury initiated the Troubled Asset Relief Program (TARP) in fall 2008, which eventually took the form of the government purchasing equity capital in over 600 commercial banks nationwide. Nearly $\$ 200$ billion has been spent on the capital purchases. As noted earlier, the risk capital of the financial sector has fallen in this crisis. TARP is an effort to offset some of the lost capital. However, note that TARP is directed primarily to commercial banks, and commercial banks are only a subset of the actors in the financial sector. Thus, other policies were needed if the goal was to have a direct effect on the rest of the financial sector.

A second initiative was an alteration of the traditionally Federal Reserve "discount window" whereby commercial bank may receive loans, while pledging some collateral to the Fed. This discount window facility is essentially a repo loan that the Fed has made available to commercial banks. Prior to 2007, the collateral was most commonly bonds issued by the U.S. Treasury or a government-sponsored agency. But since 2007, the discount window has altered its practices in two ways. One change is that the Fed has expanded the facility to lend to "primary bond dealers" (for example, Goldman, Sachs, Morgan Stanley and other noncommercial banks) following the failure of Bear Stearns. Since the majority of debt market trades and repo loans flow through these bond dealers, the expansion of the discount window provides them alternative financing to offset the problems in the repo market. The other major change in discount window policy has been to broaden the class of debt instruments that the Fed accepts as collateral. In many cases, the Fed now charges lower haircuts on this collateral than the private repo market. It is difficult to compare these haircuts directly, because there is heterogeneity among assets, but for some of the tranches of subprime mortgage-backed securities, the private market haircuts are 100 percent, while the Fed offers haircuts around 20 percent.

In a third policy step, the Federal Reserve and Treasury have initiated a Term Asset-Backed Lending Facility (TALF). TALF offers repo loans against the collateral of newly issued assetbacked securities, for a loan maturity of up to three years. For many of these securities, the private repo market offers only overnight loans, or has shut down. In some markets, there is virtually no new issuance of certain asset-backed securities because investors cannot obtain the repo necessary to purchase the securities; for example, a credit card lender may not be able sell off credit card loans into a secondary market. This shift can be costly to an end-consumer, because it tends to tighten the supply of consumer credit. TALF is an effort to offset the maturity shortening of the private repo market, and in the process, expand the market's capacity for absorbing new asset-backed securitizations. In a similar vein, traditional discount 
window loans from the Federal Reserve were overnight loans to commercial banks. During the financial crisis, the Fed has offered longer-term 28-day discount window loans. This initiative is also to offset the maturity contraction that has taken place in private debt markets.

A fourth step is that the Federal Reserve and the government-sponsored enterprises have been purchasing mortgage-backed securities since the end of 2008 (see the "Press Release" of November 25,2008 , at

$<$ http://www.federalreserve.gov/newsevents/press/monetary/20081125b.htm >). Plans are in place to purchase in excess of $\$ 1$ trillion of mortgage-backed securities issued by governmentsponsored enterprises. This initiative is an effort to directly purchase assets that may be trading below fundamental value. In addition, to the extent that these assets are removed from the balance sheets of financial institutions, their mortgage risks and their probability of financial distress falls. As a result, it is plausible that financial institutions become less risk averse towards taking the risks of new additional lending.

These initiatives all affect different aspects of the limits of arbitrage problem. However, in order to draw conclusions on the merits of each of these initiatives, it is necessary to understand the cause of the limits of arbitrage problems and the advantage of the government relative to the private sector in overcoming these problems. Let me conclude by offering my views on where such an advantage may lie.

As I have discussed, there are perverse feedback effects that have played a role in the malfunctioning of debt markets. In the risk-capital context, falling asset prices decrease risk capital, increasing financial institutions' risk aversion, further reducing asset prices. In the haircut context, falling liquidity raises haircuts, reducing repo activity and trading, further reducing liquidity. These types of feedbacks are indicative of externalities. Indeed, a number of papers formally study these type of externalities and describe policies to improve outcomes; Krishnamurthy (2009) reviews some models of this financing externality. Take the risk capital feedback I have described. A given firm will see a lower benefit of selling equity to increase its risk capital, relative to the benefit for the whole financial sector, because of the external effect that the firm's risk capital has on other firms' risk capital. A related argument is that the financial sector is systemically important since it is essential for credit extension to the real economy. Thus, any impairment in the financial sector leads to a reduction in real activity. If the financial sector does not internalize this effect, then again it may undervalue risk capital. Since the government can internalize these externalities in their decisions, one can offer a rationale for why the government should inject capital in the financial sector. 
Another advantage of the government relative to the private sector is that the government has little (or no) demand for liquidity; that is, if the government needs cash, it can issue Treasury bills. The evidence I have provided on the behavior of Treasury bill interest rates indicates that the private sector places an enormous value on these securities. Thus, at the horizons that this credit crisis will play out, the government has no need to remain liquid. On the other hand, almost all private investors value retaining some liquidity in their investments. The policy initiatives, especially those involving the expansions of the discount window and Term AssetBacked Lending Facility (TALF), essentially take advantage of the differential demand for liquidity. Repo haircuts are high and maturities are short because private lenders are averse to being illiquid. The government can offer lower haircuts and longer maturity repo loans, since it does not face liquidity considerations.

These arguments I have offered on the beneficial effects of policy interventions during the crisis also have ramifications for policy in advance of crises. Take the risk capital externality I have outlined. The argument also implies that the financial sector will have too little risk capital and too much debt during "normal" periods, leaving the economy more prone to crises, as Krishnamurthy (2009) explains formally. Moreover, as is widely recognized, if the central bank intervenes during a crisis to reduce feedback effects, then such anticipated interventions creates a moral hazard problem that distorts financing choices during normal periods. For these reasons, prudential policy should be geared toward requiring firms to carry higher capital levels. More generally, the fallout during this crisis points to challenges going forward: regulation needs to be geared towards creating financial/organizational structures that are less prone to crises. Similarly, I have argued that the U.S. government can provide liquidity during crises because it uniquely has no liquidity needs. However, if the national debt increases rapidly, the government may one day find itself in the position that its creditworthiness is reduced to the point it too will demand liquidity. This sobering thought offers a further reminder of the policy challenges we face going forward. 


\section{REFERENCES}

Adrian, Tobias, and Hyun Shin. Forthcoming. “Liquidity and Leverage.” Journal of Financial Intermediation

Bernanke, Ben S. 2008. “Liquidity Provision by the Federal Reserve.” Speech at the Federal Reserve Bank of Atlanta Financial Markets Conference. May 13. At <http://www.federalreserve.gov/newsevents/speech/bernanke20080513.htm>.

Brunnermeier, Markus. 2009. “Deciphering the Liquidity and Credit Crunch 2007-08.” Journal of Economic Perspectives, 23(1): 77-100.

Brunnermeier, Markus, and Lesse Pedersen. 2009. "Market Liquidity and Funding Liquidity.” Review of Financial Studies, 22(6): 2201-2238.

Caballero, Ricardo and Arvind Krishnamurthy. 2008. “Collective Risk Management in a Flight to Quality Episode.” Journal of Finance, 63(5): 2195-2236.

Caballero, Ricardo and Arvind Krishnamurthy. 2009. "Financial Fragility and Global Imbalances.” American Economic Review, 99(2): 584-588.

Diamond, Douglas, and Philip Dybvig. 1983. "Bank Runs, Deposit Insurance and Liquidity.” Journal of Political Economy, 99: 401-419.

Eisfeldt, Andrea, and Adriano Rampini. 2008. Working Paper. "Financing Shortfalls and the Value of Aggregate Liquidity."

Fishman, Michael, and Jonathan Parker. 2009. Working Paper "Valuation and the Volatility of Investment”

Gabaix, Xavier, Arvind Krishnamurthy, and Oliver Vigneron. 2007. "Limits of Arbitrage: Theory and Evidence from the Mortgage Backed Securities Market.” Journal of Finance, 62(2): 557-596.

Garleanu, Nicolae, Lasse Pedersen, and Allen Poteshman. Forthcoming. "Demand-Based Option Pricing.” The Review of Financial Studies.

Garleanu, Nicolae, and Lasse Pedersen. 2007. “Liquidity and Risk Management.” American Economic Review, 97(2): 193-197.

Gorton, Gary. 2009, Working Paper. “ Slapped in the Face by the Invisible Hand: Banking and the Panic of 2007.” 
Gorton, Gary, and Andrew Metrick. 2009. Working Paper, "Securitized Banking and the Run on Repo."

Gorton, Gary, and George Pennacchi. 1990. "Financial Intermediaries and Liquidity Creation." Journal of Finance, 45(1): 49-72.

Greenwood, Robin and Dimitri Vayanos. 2007. Working Paper. Bond Supply and Excess Bond Returns.

Gromb, Denis, and Dimitri Vayanos. 2002. "Equilibrium and Welfare in Markets with Financially Constrained Arbitrageurs.” Journal of Financial Economics, 66(2-3): 361-407.

He, Zhiguo, and Wei Xiong. 2009. Working Paper. “Dynamic Debt Runs.”

He, Zhiguo, and Arvind Krishnamurthy. 2009a. Working Paper. “A Model of Capital and Crises"

He, Zhiguo, and Arvind Krishnamurthy. 2009b. Working Paper. "Intermediary Asset Pricing”

Holmstrom, Bengt. 2008. “Comments on The Panic of 2007,” by Gary Gorton, forthcoming in Maintaining Stability in a Changing Financial System, Symposium sponsored by The Federal Reserve of Kansas City at Jackson Hole, Wyoming, 2008.

Holmstrom, Bengt, and Jean Tirole. 1998. "Private and Public Supply of Liquidity." Journal of Political Economy, 106(1): 1- 39.

Hördahl, Peter, and Michael R. King. 2008. "Developments in Repo Markets During the Financial Turmoil.” Bank for International Settlements Quarterly Review December 2008: 3753.

Krishnamurthy, Arvind. 2002. “The Bond/Old-Bond Spread.” Journal of Financial Economics, 66(2): 463-506.

Krishnamurthy, Arvind. Forthcoming. “Amplification Mechanisms in Liquidity Crises.” American Economic Journals: Macroeconomics.

Krishnamurthy, Arvind, and Annette Vissing-Jorgensen. 2008. Working Paper. "The Aggregate Demand for Treasury Debt”

Shleifer, Andrei, and Robert Vishny. 1997. “The Limits of Arbitrage.” Journal of Finance, 52(1): 35-55.

Vayanos, Dimitri. 2004. Working Paper. "Flight to Quality, Flight to Liquidity, and the Pricing of Risk.” 


\section{Table 1}

\section{Debt Market Size}

\section{(\$ billions)}

\begin{tabular}{|c|c|c|c|}
\hline Loans & Outstanding & Securities & Outstanding \\
\hline $\begin{array}{l}\text { Subprime mortgage } \\
\text { loans }\end{array}$ & 300 & Asset-backed securities & 1750 \\
\hline Alt-A mortgage loans & 600 & $\begin{array}{l}\text { Asset-backed securities in } \\
\text { the form of collateralized } \\
\text { debt obligations }\end{array}$ & 400 \\
\hline Prime mortgage loans & 3800 & $\begin{array}{l}\text { Prime mortgage-backed } \\
\text { securities }\end{array}$ & 3800 \\
\hline $\begin{array}{l}\text { Commercial Real } \\
\text { Estate }\end{array}$ & 2400 & $\begin{array}{l}\text { Commercial mortgage- } \\
\text { backed securities }\end{array}$ & 940 \\
\hline Corporate Loans & 3700 & $\begin{array}{l}\text { High-grade Corporate } \\
\text { Debt } \\
\text { Collateralized loan } \\
\text { obligations }\end{array}$ & $\begin{array}{l}600 \\
350\end{array}$ \\
\hline Total for Loans & $\$ 10,800$ & Total for Securities & $\$ 7,840$ \\
\hline
\end{tabular}

Source: IMF Global Financial Stability Report October 2008, Table 1.1. 


\section{Table 2}

\section{Financial Institution Assets}

\section{(\$ billions)}

\begin{tabular}{lr}
\hline \multicolumn{1}{c}{ Financial Institution } & Total Assets \\
\hline Commercial Banks & $\$ 11,192$ \\
Insurance Companies & 6,308 \\
GSEs & 3,174 \\
Brokers and Dealers & 3,092 \\
Hedge Funds & 3,406 \\
\hline
\end{tabular}

Sources: Flow of Funds of Federal Reserve 2007, He and Krishnamurthy (2008). 
Table 3

Losses, by Financial Institution and Debt Instrument

(\$ billions)

\begin{tabular}{|c|c|c|c|c|}
\hline & \multirow[t]{2}{*}{$\begin{array}{l}\text { Amounts } \\
\text { Outstanding }\end{array}$} & \multicolumn{3}{|c|}{$\begin{array}{c}\text { Estimated } \\
\text { Losses and } \\
\text { Writedowns }\end{array}$} \\
\hline & & Banks & Insurers & $\begin{array}{l}\text { Hedge Funds } \\
\quad+\text { Other }\end{array}$ \\
\hline Real Estate Loans & $\$ 7100$ billion & 150 & 15 & 40 \\
\hline$A B S+A B S C D O s$ & 2150 & 260 & 110 & 40 \\
\hline $\begin{array}{l}\text { Prime mortgage-backed } \\
\text { securities }\end{array}$ & 3800 & 20 & 10 & $<5$ \\
\hline $\begin{array}{l}\text { Commercial mortgage- } \\
\text { backed securities }\end{array}$ & 940 & 85 & 25 & 20 \\
\hline Corporate Debt + CLOs & 4650 & 135 & 40 & 30 \\
\hline Total & 17920 & 650 & 200 & 135 \\
\hline
\end{tabular}

Source: IMF Global Financial Stability Report October 2008, Table 1.1 


\section{Table 4}

\section{Repo Haircuts}

\begin{tabular}{|c|c|c|c|c|}
\hline & \multicolumn{4}{|c|}{ Repo Haircuts } \\
\hline & $\begin{array}{l}\text { Spring } \\
2007\end{array}$ & $\begin{array}{c}\text { Spring } \\
2008\end{array}$ & $\begin{array}{l}\text { Fall } \\
2008\end{array}$ & $\begin{array}{l}\text { Spring } \\
2009\end{array}$ \\
\hline US Treasuries (short-term) & $2 \%$ & $2 \%$ & $2 \%$ & $2 \%$ \\
\hline US Treasuries (long-term) & 5 & 5 & 6 & 6 \\
\hline Agency Mortgage-Backed Securities & 2.5 & 6 & 8.5 & 6.5 \\
\hline $\begin{array}{l}\text { Corporate Bonds } \\
\text { A-/A3 or above }\end{array}$ & 5 & 10 & 20 & 20 \\
\hline $\begin{array}{l}\text { Collateralized Mortgage Obligations } \\
\text { (CMOs) AAA }\end{array}$ & 10 & 30 & 40 & 40 \\
\hline $\begin{array}{l}\text { Asset Backed Securities (ABS) } \\
\text { AA/Aa2 and above }\end{array}$ & 10 & 25 & 30 & 35 \\
\hline
\end{tabular}

Source: DTCC, Investment Bank Reports 


\begin{tabular}{|c|c|c|c|c|}
\hline $\begin{array}{l}\text { Repo Borrowers } \\
\text { (Trading Desks, } \\
\text { Hedge Funds) }\end{array}$ & $\underset{\text { Cash }}{\stackrel{\text { Collateral }}{\longrightarrow}}$ & $\begin{array}{l}\text { Wall } \\
\text { Street } \\
\text { Banks }\end{array}$ & $\underset{\text { Cash }}{\stackrel{\text { Collateral }}{\longrightarrow}}$ & $\begin{array}{l}\text { Repo Lenders: Institutional } \\
\text { Cash Investors including } \\
\text { Other Banks, Money } \\
\text { Market Funds, Corporations }\end{array}$ \\
\hline
\end{tabular}

Figure 1: Flows in the Repo Market 


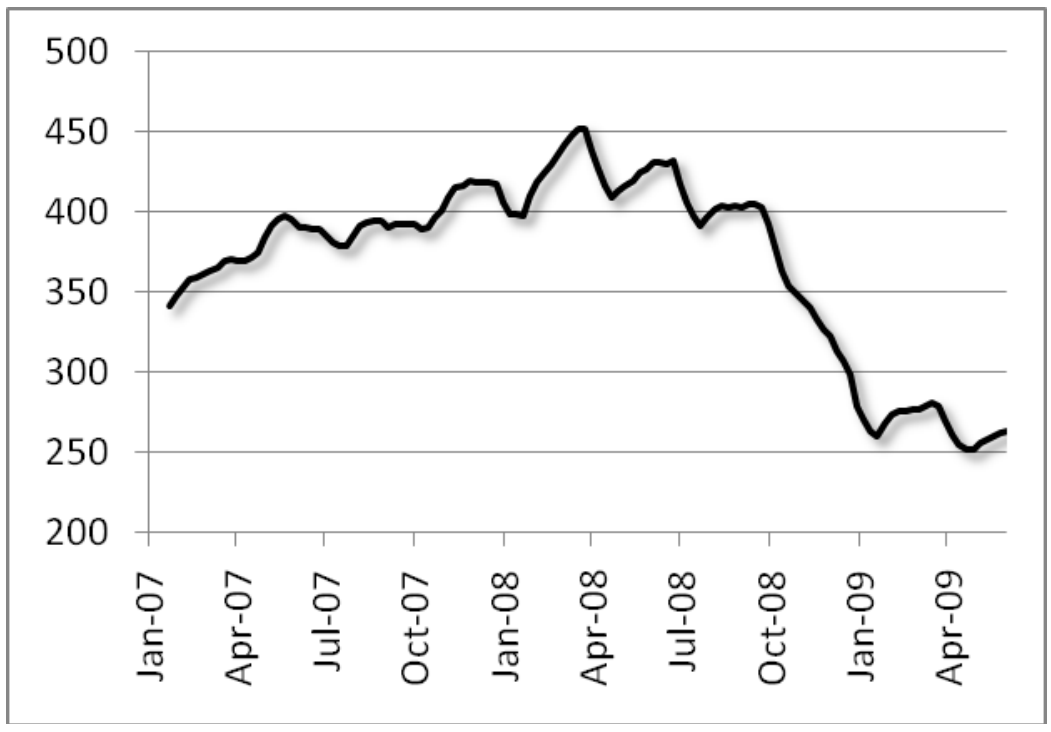

Figure 2: Dealer Repo Activity (\$Billions, Rolling Monthly Average) Source: Federal Reserve Bank of New York 


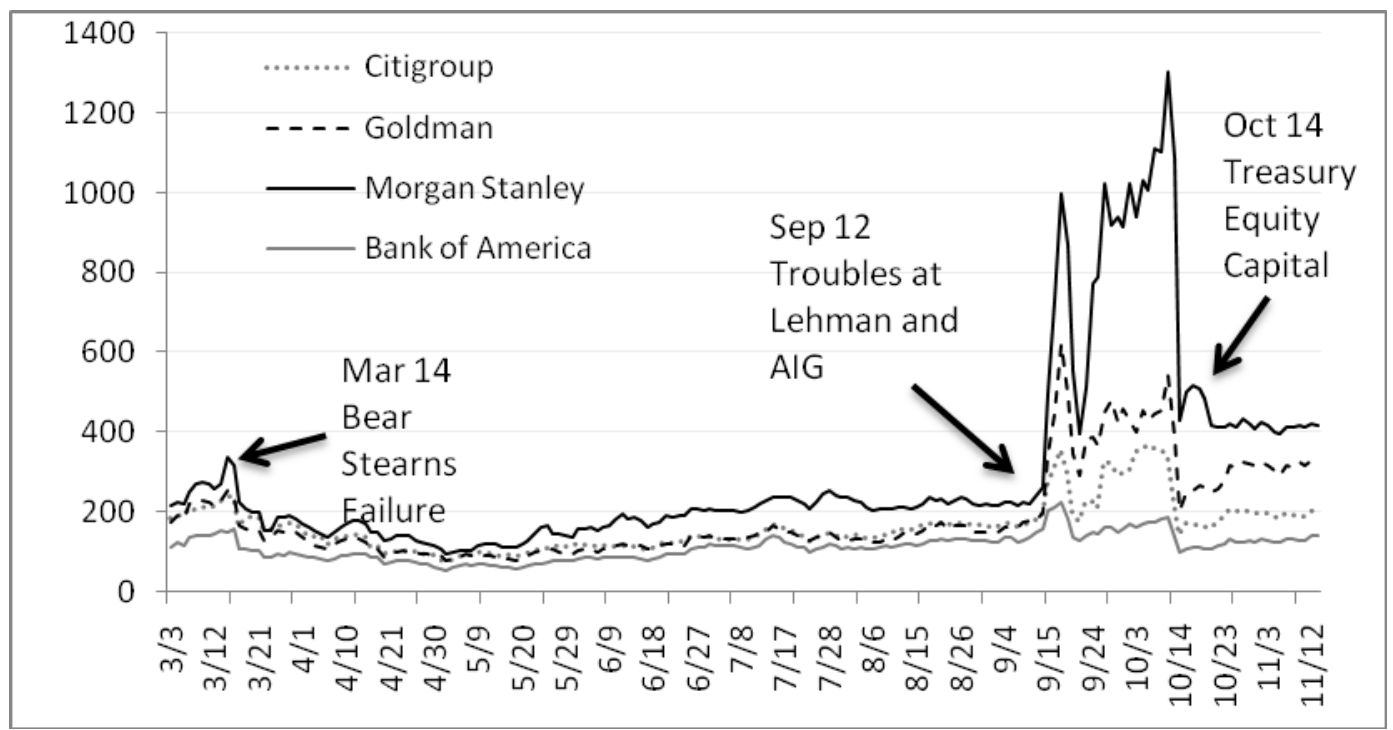

Figure 3: CDS Rates (Basis Points)

Source: Datastream 
FNMA BONDS

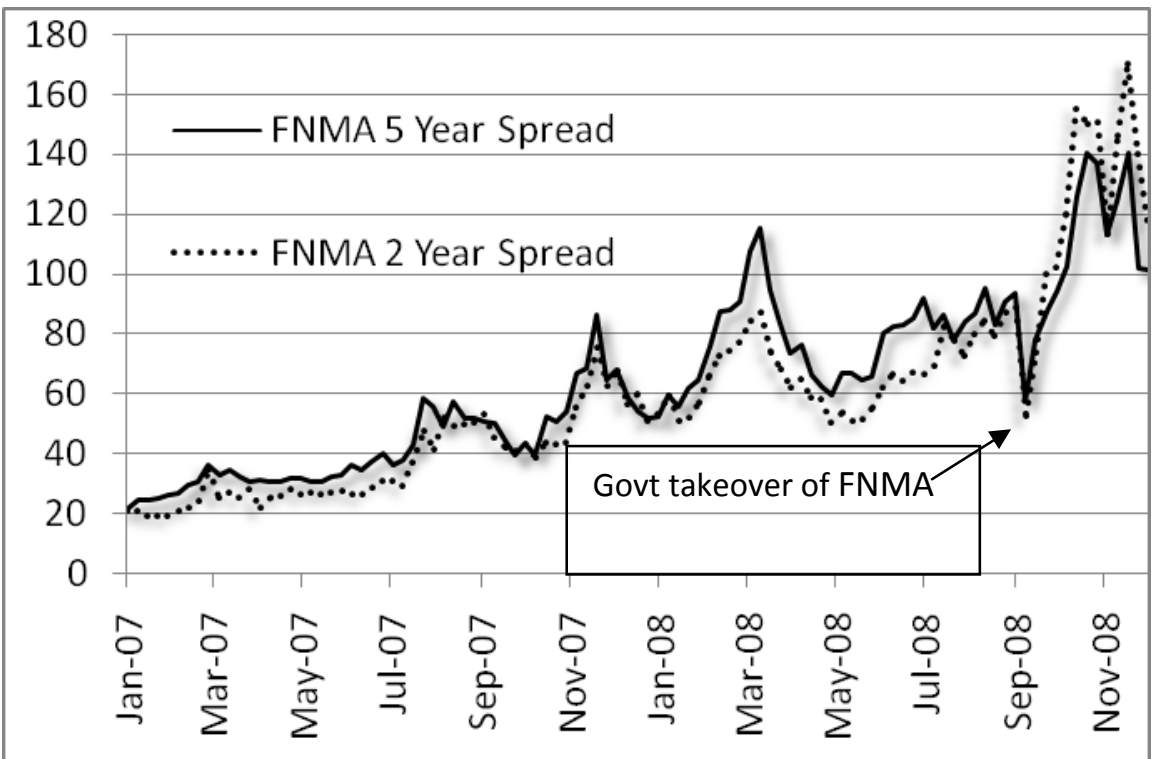

Figure 4: FNMA Spreads to Treasuries (bps)

Source: Bloomberg 


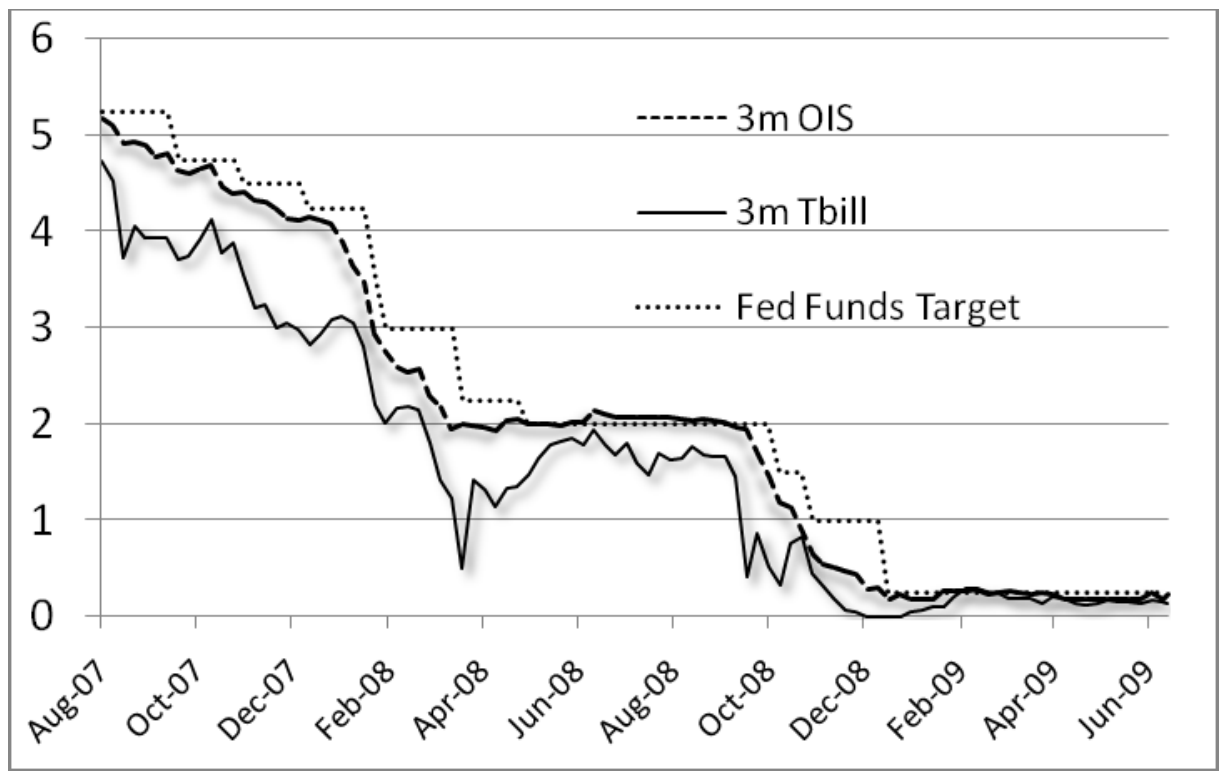

Figure 5: 3-Month Treasury Bill, 3-Month OIS, Fed Funds Target (\%) Source: Bloomberg 


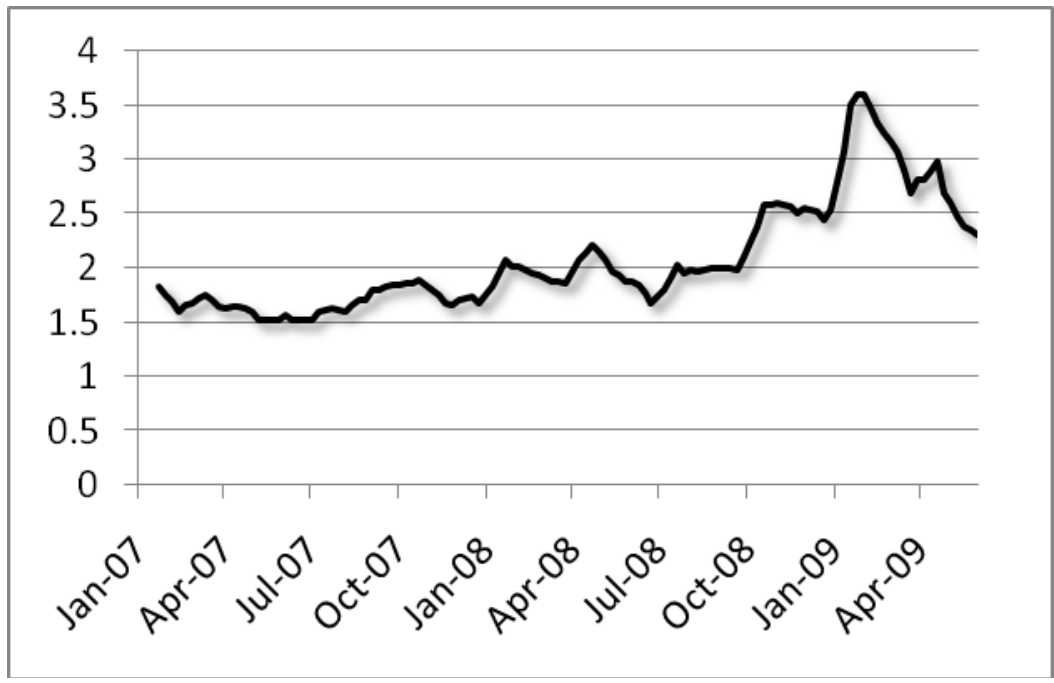

Figure 6: Ratio of Overnight Repo to Term Repo (1 Month Average) Source: Federal Reserve Bank of New York 


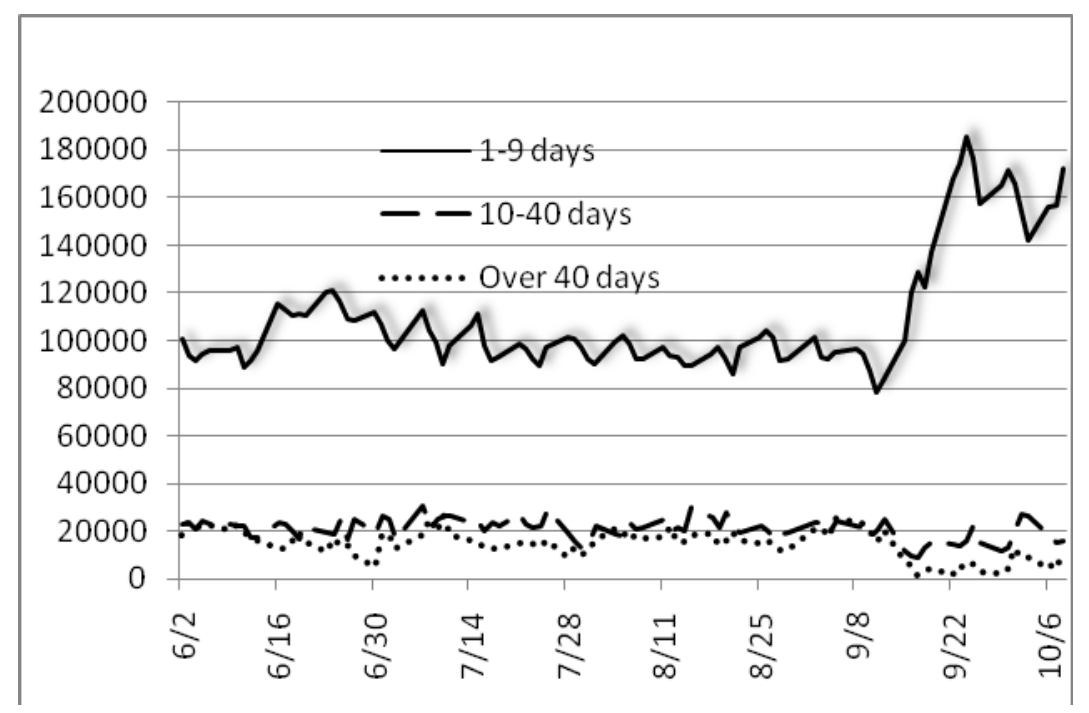

Figure 7: Commercial Paper Issuance (Millions of \$) Source: Federal Reserve 


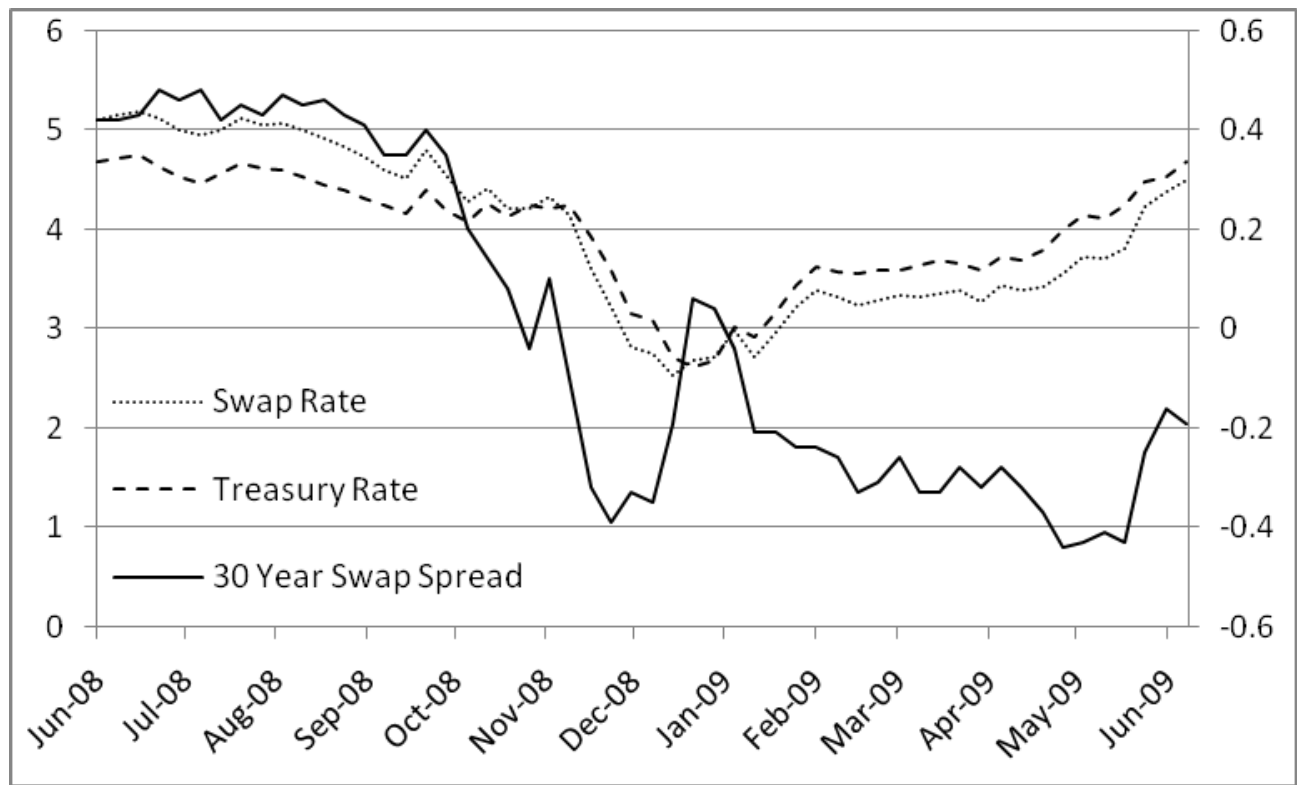

Figure 8: 30 Year Swaps. Interest Rates (left-axis) and Spread (right-axis) in\%. Source: Federal Reserve 


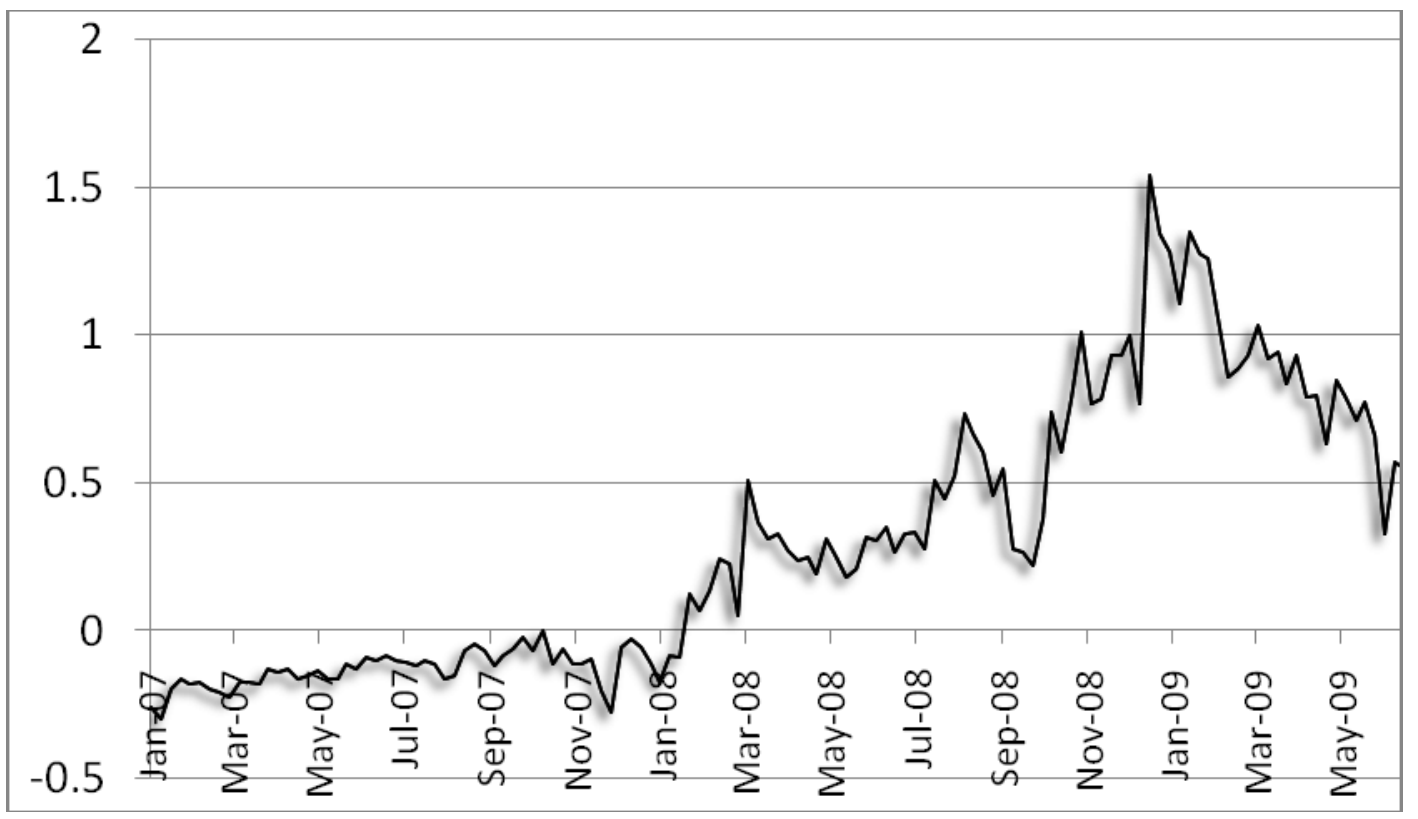

Figure 9: OAS on GNMA 6s versus Swap Rates (\%)

Source: Bloomberg 